\title{
Teikuma priekšmeta, izteicēja un papildinātāja novietojums teikumā un teikuma intonācija latviešu valodā
}

\section{Word order and intonation in a sentence in Latvian}

\author{
Baiba Saulīte, Ilze Auziṇa, Kristīne Levāne-Petrova \\ Latvijas Universitātes Matemātikas un informātikas institūts \\ Raiņa bulvāris 29, Rīga, LV-1050 \\ E-pasts: baiba.saulite@lumii.lv,ilze.auzina@lumii.lv, \\ kristine.levane-petrova@lumii.lv
}

\begin{abstract}
Vārdu pamatsecība ir viena no pazīmēm, pēc kuras valodas tiek klasificētas noteiktos tipos. Latviešu valoda pieder pie valodām ar brīvu vārdu secību, bet par tās pamatsecību uzskatāma secība teikuma priekšmets-izteicējs-papildinātājs (SVO).

Rakstā vispirms analizēta latviešu valodas vārdu pamatsecība un citi vārdu secības modeḷi, kā arī konstatētas no pamatsecības atšksirīgo vārdu secības modeļu galvenās īpatnības.

Raksta otrajā daḷā analizēts, vai latviešu valodā mainītu vārdu secību papildina arī kādas prosodiskās īpatnības un vai ir vērojamas tipiskas intonācijas iezīmes noteiktām teikuma priekšmeta, izteicēja un papildinātāja kombinācijām. Aplūkotajā valodas materiālā neatkarīgi no teikuma priekšmeta, izteicēja un papildinātāja secības visbiežāk uzsvērtas intonatīvās frāzes beigas. Ja intonatīvā frāze beidzas ar teikuma priekšmetu vai papildinātāju, paralēli uzsvaram intonatīvās frāzes beigās var būt uzsvērts arī izteicējs.
\end{abstract}

Atslēgvārdi: vārdu pamatsecība, vārdu secības modeḷi, intonatīvā frāze, uzsvars.

Rakstā iztirzāti kritēriji, pēc kuriem tiek identificēta kādas valodas vārdu pamatsecība, aprakstīta latviešu valodas vārdu pamatsecība, ieskicēts papildinātāja tipiskais novietojums, kā arī analizēti vārdu secības model̦i, kuri konstatēti dažādos Latvijas Universitātes Matemātikas un informātikas institūta Mākslīgā intelekta laboratorijā veidotos resursos:

1) Līdzsvarotā mūsdienu latviešu valodas tekstu korpusā (turpmāk tekstā - LVK);

2) Latviě̌u valodas verbu valences datubāzēe (turpmāk tekstā - „Valences datubāze");

3) Latviešu valodas runas korpusā (turpmāk tekstā - LVRK).

\section{Vārdu pamatsecības noteikšanas kritēriji}

Vārdu secības tipologijāà dominē uzskats, ka uz katru valodu var attiecināt noteiktu pamatsecību (angl̦u val. basic word order) - ne tikai izteicēja (V), teikuma priekšmeta $(\mathrm{S})$ un papildinātāja $(\mathrm{O})^{1}$ pamatsecību, bet arī, piem., nomena un

1 Rakstā izmantoti valodu tipoloǵiskās klasifikācijas aprakstā tradicionālie teikuma priekšmeta (S), izteicēja (V) un papildinātāja (O) apzīmējumi (sk. arī Greenberg 1990). 
adjektīva novietojumu nominālā vārdkopā. Tomēr ne vienmēr ir skaidrs, ko saprast ar pamatsecību. Ja valodā ir iespējama tikai viena vārdu secība, par pamatsecību un tās klasifikāciju šaubu nav. Tās rodas gadījumos, kad valodā parādās vairāki iespējamie vārdu secības model̦i. Pamatsecības identificēšanai tiek piedāvāti vairāki kritēriji, piem.:

1) noteiktas secības biežums tekstā,

2) biežums gramatikas sistēmā (piem., vairāk adjektīvu noteiktā novietojumā attiecībā pret lietvārdu),

3) gramatiski nemarķēts statuss (Hawkins 1983, 13).

Arī gadījumos, kad valodā iespējami vairāki alternatīvi vārdu secības modelii, viens no modeliem parasti tiek lietots biežāk (Dryer 2007, 71), tātad pamatsecīibas identificēšanā nozīmīgs kritērijs ir noteiktas secības biežums tekstā.

Lai arī ir ierasts aplūkot visus sešus iespējamos teikuma priekšmeta, izteicēja un papildinātāja model̦us, amerikāņu tipologs Džozefs Grīnbergs (Joseph Greenberg) pieņem, ka jebkura valoda pieder pie viena no trim šo komponentu izkārtojuma model̦iem - SVO (piem., angḷu valoda), SOV (piem., japāņu valoda) un VSO (piem., velsiešu valoda). Dž. Grīnbergs (Greenberg 1990, 44) norāda, ka pārējie secības model̦i - VOS, OSV un OVS, t. i., tie, kur teikuma priekšmets novietots aiz papildinātāja, kā dominējošie neparādās vai arī parādās l̦oti reti.

Valodu tipolog̣ijā ir izveidojusies tradīcija valodas pēc vārdu secības īpatnībām iedalīt četrās vispārinātās grupās:

1) valodas, kurās teikuma priekšmets un papildinātājs novietots izteicēja priekšā (verb-final valodas), - valodas ar SOV (pasaulē visvairāk izplatītā secība) un OSV secību;

2) valodas, kurās izteicējs novietots pirms teikuma priekšmeta un papildinātāja (verb-initial valodas), - valodas ar VSO un VOS secību;

3) SVO valodas, kas pēc izplatības ierindojas otrajā vietā aiz valodām, kurās teikuma priekšmets un papildinātājs novietots izteicēja priekšā;

4) valodas, kurās ir prepozitīvs papildinātājs (object-initial valodas), šajā grupā ietilpst visretāk sastopamās valodas, resp., valodas, kurās dominē model̦i OVS un OSV (Dryer 2007, 125).

Lai gan šāda valodu klasifikācija pamatā balstās uz valodām ar fiksētu vārdu secību un valodas ar brīvu vārdu secību pašas par sevi ir atseviškss valodas tips, tās, ņemot vērā biežāk sastopamo secību, parasti iekḷaujas kādā no minētajām vārdu secības grupām (Dryer 2007, 100), piem., latviešu valodu nešaubīgi var pieskaitīt SVO valodu grupai ar brīvu vārdu secību.

Daudzām valodām ar brīvu vārdu secību ir raksturīgi, ka vārdu secība vieniem elementiem ir brīva, bet citiem - fiksēta, piem., latviešu valodā teikuma līmen̄̄ secība ir diezgan brīva, tai pat var nepiemist nekāda īpaša papildinformācija, piem., nav sevišķu atšksirību teikumos:

(1) a. *Caur loga vitrāžām krīt zeltaina gaisma²;

b. Zeltaina gaisma krīt caur loga vitrāžām. (LVK)

2 Šeit un turpmāk ar zvaigznīti (*) apzīmēti teikumi, kuros transformēta oriǵinālā teikuma vārdu secība. 
Turpretim, mainot apzīmētāja novietojumu vienkāršā lietvārda vārdkopā, var pievienoties īpaša papildnozīme, piem., teikumam (2b) salīdzinājumā ar (2a) piemīt emocionāla ekspresija:

(2) a. *vinas rokās līst zelta asinis;

b. vinas rokās līst asinis zelta. (LVK)

Analizējot valodas ar brīvu vārdu secību, nav skaidrs, vai uz šīm valodām var attiecināt kaut kādus vispārinājumus. Šķiet, ka lietderīgāk ir runāt par noteiktiem novērojumiem, piem., kurās konstrukcijās secība ir brīva un kur nav, tāpat var pētīt, kāda secība ir ierastāka (sk. arī Zilgalve 2009), tāpēc tālāk analizēti dažādi vārdu secības modeli latviešu valodā.

\section{SVO un citi vārdu secības modeḷi „Valences datubāzē”}

Lai kvantitatīvi novērtētu teikuma priekšmeta, izteicēja un papildinātāja secības īpatnības un tipiskos modelıus latviešu valodā, tika veikts eksperiments, izmantojot „Valences datubāzi” (par to sk. arī Nešpore et al. 2012; Nešpore, Saulīte 2013), kur aplūkoti 15 pārejoši verbi, kas konkrētajā lietojumā piesaista teikuma priekšmetu un tiešo papildinātāju. Kopumā skatīts vairāk nekā 1000 teikumu ar dažādiem teikuma priekšmeta, izteicēja un papildinātāja secības modeḷiem (statistiku sk. 1. attēlā. Vārdu secības modẹ̦i „Valences datubāzē”). „Valences datubāzē" konstatēti visi seši iespējamie vārdu secības model̦i, no kuriem model̦i ar izteicēju teikuma priekšmeta un papildinātāja priekšā - VSO un VOS - sastopami tikai pāris reižu. Jāpiebilst, ka šajā eksperimentā atškirībā no eksperimenta LVRK uzmanība netika pievērsta nepilniem teikumiem (t. i., teikumiem, kur papildinātājs vai teikuma priekšmets reducēts), resp., nav analizēti model̦i OV un VO, kā arī SV un VS.

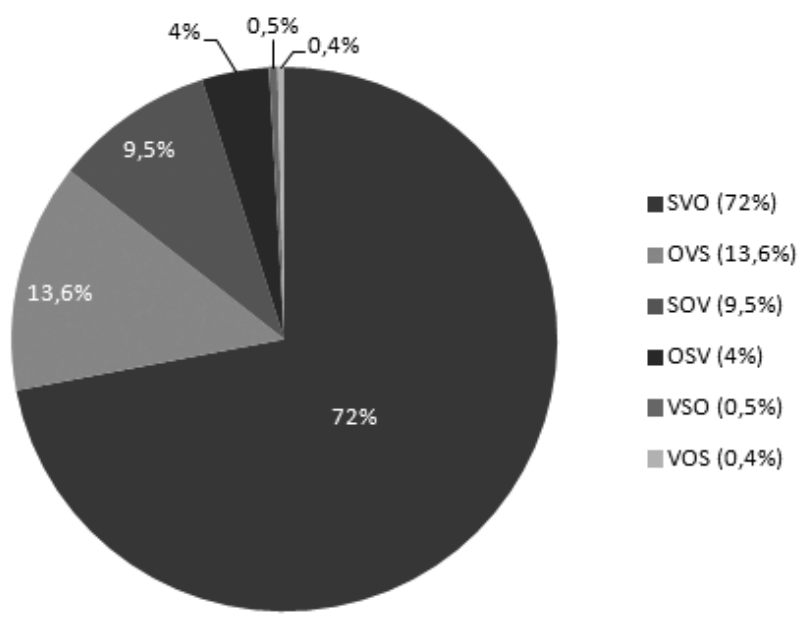

1. attēls. Vārdu secības modeḷi ,Valences datubāzē”. 
Kā jau minēts, SVO ir latviešu valodas vārdu pamatsecība - biežākā vārdu secība, ko ierasti uzskata arī par neitrālu jeb pragmatiski nemark̦ētu secību. Šāda secība ir iespējama dažādās teikumu konstrukcijās (piem., dažādos komunikatīvajos tipos, arī palīgteikumos). Teikuma priekšmets šajā modelī var būt teikuma sākumā, piem.:

(3) Vinšs lēni un bijīgi nesa manani cauri vēsajai dūmakai;

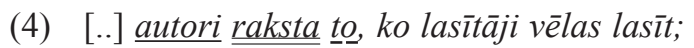

(5) [..] kura 호steno apjomīgo Eiropas Regionālās attīstības fonda ERAF finansēto projo르느.

Teikuma priekšmets var būt arī aiz citiem teikuma paplašinātājiem vai partikulas, piem.:

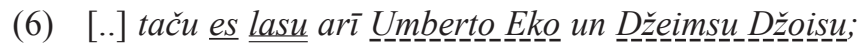

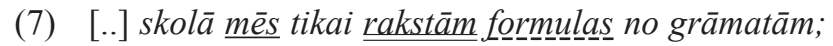

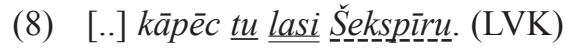

Otra biežākā secība aplūkotajos datos ir OVS. Šai secībai raksturīgs tiešais papildinātājs pašā teikuma sākumā. Teikuma priekšmets parasti ir jaunā informācija, bet ar papildinātāju izteiktā informācija visbiežāk jau ir parādījusies konsituācijā.

(9) Katru vina a $\underline{\text { und }} \underline{\mathrm{u}}$ pildīja prieks;

(10) Ko meklē sieviete, kuru savaldzinājis [..];

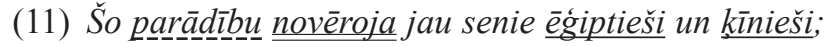

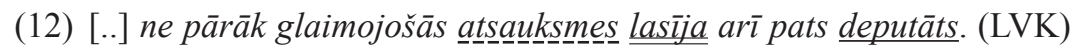

Teikuma sākumā novietotam papildinātājam var arī nepiemist pazīme konsituatīvi saistīts. Tādā gadījumā tas veic tikai ziņojuma sākumpunkta funkciju bez citas pragmatiski noteiktas papildinformācijas, piem.:

(13) [..] fotogrāâfizas par fona attēliem [..] vislabprātāk izvēlas gandrīz visu vecuma grupu pārstāvji [..];

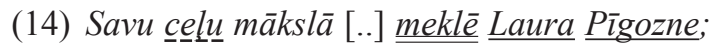

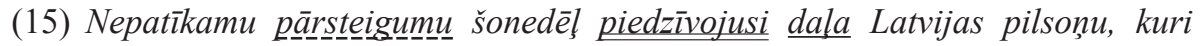
dzīvo ārpus dzimtenes. (LVK)

Modelī SOV papildinātājs visbiežāk ir konsituatīvi saistīts, piem.:

(16) Leons tevi $\underline{\text { meklē; }}$

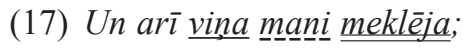

(18) [..] pat Nora Ikstena savulaik kạut_ko rakstīja par dzīves svinēšanu.

Šis nosacījums bieži kombinējas ar papildpazīmi, ka modelis lietots palīgteikumā vai virsteikumā, kas pieprasa noteiktu secību, kā arī jautājuma teikumos, piem.:

(19) Kur jūus to $\underline{\text { lasījātt? }}$

(20) Kā jūs to reāli iㅗtenosiet? 


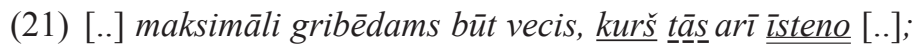

(22) Pēdèjā pusgadā vērojama tendence, ka pircēji préeces $\underline{\underline{i z v e ̄ l a s ~}}$ rūpīgāk. (LVK)

Savukārt teikuma priekšmets, kā redzams iepriekšējos piemēros (17), (18), lai arī visbiežāk šajā modelī ir teikuma sākumā, informatīvi ir diezgan nozīmīgs, var būt uzsvērts arī ar partikulām.

Teikumos, kuros novērota secība OSV, raksturīgi, ka papildinātājam galvenokārt ir strukturāla nozīme - saikḷa vai jautājamā vārda funkcijā palīgteikumos:

(23) Ko es tur pie šiem meklēšu?

(24) Ko nozīmē tas čeks, uuru tu izrakstīji Grosas jaunkundzei [..].(LVK)

Tāpat šādas secības teikumos papildinātājs bieži ir izteikts ar norādāmajiem vietniekvārdiem, tātad ir konsituatīvi saistīts, bet vienlaikus arī uzsvērts, piem.:

(25) Tāas audzēkni lasa visur.

Papildinātājs šajā model̄i var būt izteikts arī ar pilnnozīmes vārdiem. Tādā gadījumā tam teikuma informācijas struktūrā ir lielāka nozīme nekā teikuma priekšmetam:

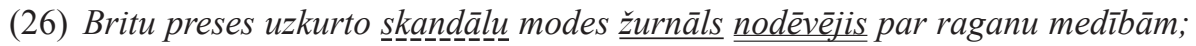

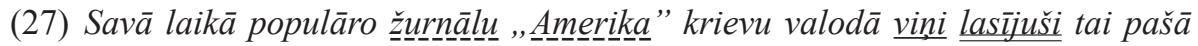
dienā, kad [..];

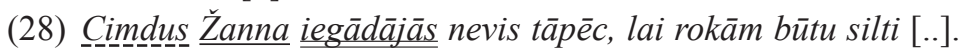

Kā jau minēts, model̦i VSO un VOS ir ļoti netipiski - konstatēti tikai septiņi gadījumi aptuveni 1000 apskatītajos teikumos - pārsvarā palīgteikumos un daiḷliteratūrā - sarunvalodas attēlojumā vai dzejā, piem.:

(29) [..], lai gan nokēris to vēl neviens nebija;

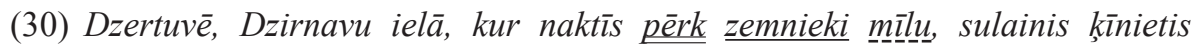
pasniedza alu [..];

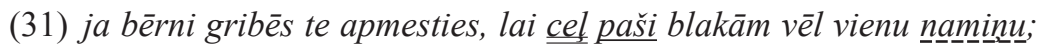

(32) Lasīju tātad es to burvju žuㅡ므믄 un uzdūros sarakstam;

(33) Vārdsakot, pārdeva vini čigāniem villku par teļu;

(34) Bet pēkšnni Stefans saka: "Pērc tu to to sev."

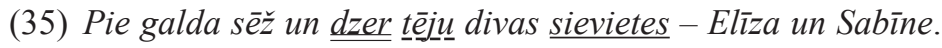

„Valences datubāze” atklāj noteiktas vārdu secības tendences latviešu valodā, kā arī pierāda, ka SVO ir latviešu valodas vārdu pamatsecība gan pēc lietojuma biežuma, gan arī pēc tā, ka tā drīzāk nekā citas uzskatāma par pragmatiski nemarķētu vārdu secību, t.i., prototipisko vārdu secību. Tāpat var secināt, ka secība VOS un VSO latviešu valodā parasti ir pragmatiski marķēta. Kad noskaidrota latviešu valodā dominējošā vārdu secība, svarīgi saprast, kāda vārdu secība raksturīga runātā valodā un vai noteiktus vārdu secības modeḷus raksturo kaut kādas intonatīvas īpatnības. 


\section{Teikuma intonācija latviešu valodā}

Intonatīvās parādības latviešu valodā aplūkotas Latviešu valodas runas korpusā. Intonācija un pauzes galvenokārt noteiktas, analizējot spektrogrammas, kur attēlota arī pamattoņa līkne (sk. 2., 3., 4. attēlā tumšāko/zemāko līkni) un intensitātes līkne (sk. 2., 3., 4. attēlā gaišāko/augstāko līkni). Uzsvars visbiežāk noteikts, gan analizējot intensitātes un pamattoņa līkni, gan izmantojot auditìvu analīzi.

Pētot teikuma intonāciju, ir svarīgi definēt intonatīvās frāzes jēdzienu. Ar intonatīvo frāzi (sintagmu) tiek saprasts vārds vai jēdzieniski saistītu vārdu grupa, kas runas plūsmā intonatīvi nodalīta (Skujiņa 2007, 355). Katru intonatīvo frāzi parasti raksturo arī log̣iskais uzsvars, kas ir kāda intonatīvās vienības vārda izcēlums runā, ko panāk ar fonētisko līdzekḷu - intensitātes, pamattoṇa augstuma maiņas, ilguma un reizēm arī ar tembra - palīdzību (Ceplitis 1974, 89; Auziña 2013, 112) un kas latviešu valodā bieži ir intonatīiās frāzes beigās (Ceplīis, Katlape 1960, 125). Veiktajos eksperimentos mēǵināts identificēt arī palīguzsvaru jeb sekundāro izcēlumu, kas ir vājāks par log̣isko uzsvaru (Skujiṇa 2007, 275). Teikumā ar vairākām intonatīvajām frāzēm visbiežāk ir atrodams uzsvars, kas ir intensīvāks par pārējiem un kas būtu uzskatāms par teikuma uzsvaru (šis uzsvars pasaules valodnieku darbos saukts arī par intonācijas centru (angḷu val. - intonation centre), sk. Hajičová et al. 1998, 105). Parasti arī galvenā intonatīvā frāze un teikuma uzsvars atrodas teikuma beigās.

Kā jau minēts, log̣iskais uzsvars visbiežāk atrodas intonatīvās frāzes beigās, turklāt raksturīgi, ka loǵiskais uzsvars ir tajos vārdos, kas izsaka kaut ko jaunu, klausītājam vēl nezināmu, un palīdz izprast runas saturu, bet logisiskajam uzsvaram var piemist arī papildnozīme - pretstatījuma nozīme (Ceplītis, Katlape 1960, 124-126), kas l̦auj izcelt komponentu, kurš tiek pretstatîts kaut kam iepriekš minētam. Savukārt emocionālā runā to ir grūtāk izdarīt, jo tad intonatīvajā frāzē skaḷāk tiek izrunāti vairāki vārdi un tāpēc viennozīmīgi nav nosakāma log̣iskā uzsvara vieta (Auziņa 2013, 112). Tātad loǵiskajam uzsvaram līdzīgs uzsvars (turpmāk tekstā atzīmēts ar versāliem) var būt arī intonatīvās frāzes sākumā, piem., gadījumos, kad izteikuma sākumā atrodas informācija, kas kaut kam pretstatīta (Matthews 2007, 79), tad uzsvars teikuma sākumā viens (36) vai kopā ar citiem līdzekḷiem, piem., partikulu (37), iegūst pretstatījuma nozīmi:

(36) LEONS tevi meklē;

(37) Ne jau MĒS esam vainīgi, bet gan izsoles administrators. (LVK)

Valodās ar fiksētu vārdu secību, piem., angḷu valodā, vārdu secība norāda uz teikuma priekšmeta un papildinātāja sintaktisko funkciju. Lai precizētu informācijas struktūru, angḷu valodā parasti tiek pārvietots logiskais uzsvars, bet valodās ar brīvu vārdu secību bieži tiek mainīta vārdu secība (Hajičová et al. 1998, 125, 126). Uzsvara pozīcijas lingvistiski analizējamas grūtāk nekā atšķirības vārdu secībā, turklāt šie abi informācijas struktūras izteikšanas līdzekḷi mijiedarbojas.

Tātad, norādot uz kādas vārdformas nozīmīgumu, angḷu valodā plaši tiek izmantota intonācija - atšķirīga informācijas struktūra var būt arī teikumam ar vienu sintaktisko struktūru (līdz ar to arī vienu vārdu secību), bet ar dažādu intonāciju. Piem., atbildot uz jautājumu - (38) Kas noticis ar caurulēm? -, tiek 
uzsvērtas teikuma beigas: (39) Caurules ir SAR $\overline{U S E} J U \check{S} A S$, savukārt uz jautājumu (40) Kädēl no üdenskrāna tek brūns üdens? - atbildei var būt identiska sintaktiskā struktūra, bet tiek uzsvērts teikuma sākums: (41) CAURULES ir sarūsējušas. (Vallduví, Vilkuna 1998, 82)

Arī valodās ar brīvu vārdu secību viena un tā pati sintaktiskā struktūra un vārdu secība var iegūt dažādu prosodisko struktūru - atšksirīgu loǵiskā uzsvara vietu, pamattoņa līkni, paužu izvietojumu, kas palīdz noformēt izteikumu atbilstoši komunikatīvajam mērķim. Piem., lai arī latviešu valodā ir tendence uzsvērt intonatīvās frāzes pēdējo vārdu (Ceplitis 1974, 101), vienai un tai pašai vārdu secībai var būt dažādi loǵiskie uzsvari:

(42) a. Mēs ìstenosim PROJEKTU;

b. Mēs ISTENOSIM projektu;

c. MĒS ìstenosim projektu.

\section{Uzsvērtas vienības noteiktos vārdu secības modeḷos}

Lai noskaidrotu, vai latviešu valodā mainītu vārdu secību papildina arī kādas prosodiskās īpatnības un vai ir vērojamas tipiskas intonācijas iezīmes noteiktām teikuma priekšmeta, izteicēja un papildinātāja kombinācijām,

1) izvēlēti četri pārejoši verbi, kas lietojumā piesaista tiešo papildinātāju, celt, lasìt, rakstīt, ìstenot;

2) ortogrāfiski marksētajā LVRK ${ }^{3}$ atlasīti piemēri (apmēram 150), kur konkrētie verbi lietoti finītā vai infinītā formā un piesaista tiešo papildinātāju akuzatīvā;

3) piemēros analizēta teikuma intonācija, nosakot loǵiskā uzsvara vietu, pamattoņa līknes virzību un pauzes.

Šajā eksperimentā (sk. 1. tabulu) konstatēts, ka arī runā tipiskā vārdu secība ir SVO. Tikai desmitajā dal̦ā no analizētajiem runas piemēriem parādās vārdu secība SOV, savukārt pavisam niecīgs skaits ir izteikumu ar secību OVS un OSV. Turklāt kombinācija OSV konstatēta tikai objekta palīgteikumu konstrukcijās (piemēros treknrakstā), piem.:

(44) es esmu rakstītāja un tas $\underline{\text { ko }} \underline{\text { es }} \underline{\text { rakstu }}$ patiesībà tu ļoti pareizi pateici;

(45) vai tas, $\underline{\text { ko }}$ jūs $\underline{\text { rakstat }}$ [rakstāt] tā patiešām ir. (LVRK)

3 Ortogrāfiski marḳēts LVRK (arī Runas atpazī̌sanas korpuss) paredzēts runas tehnologiju izstrādei un izveidots 2013. gadā IT kompetences centra ERAF līdzfinansētā projekta „Informācijas un komunikāciju tehnoloǵiju kompetences centrs” nozares pētījuma „Runas korpusa izveide, principi, metodes, realizācija" laikā. Tā apjoms ir 100 stundas, un tajā iekḷauti vairāk nekā 1800 dažādu vecumposmu (16-24, 25-50, 51-65, 66+) runātāju balss ieraksti. (Pinnis, Auziņa, Goba 2014). Korpusā audiomateriāli transkribēti t. s. ortogrāfiskajā transkripcijā, kas ir burtiska sacītā atveide rakstos mašīnlasāmā formā, ievērojot latviešu valodas vārdu un vārdformu pareizrakstības principus. Interpunkcija ortogrāfiskajā transkripcijā netiek izmantota, runātais tiek pierakstīts vārdiem, tostarp rakstot gan ciparus, gan arī sā̄sinājumus. Papildus tekstā tiek norādīi arī neverbālie elementi, pauzes un teksts svešvalodā. (Par ortogrāfisko transkripciju plašāk sk. http:// larko.ailab.lv/index.php/info/ortographical_transcription) 
Kombinācijas, kur gan papildinātājs, gan teikuma priekšmets novietots aiz izteicēja (VOS vai VSO), analizētajā runas materiālā netika konstatētas (sk. 1. tabulu).

\begin{tabular}{|l|r|r|r|r|r|r|r|}
\hline & \multicolumn{1}{|c|}{ SVO } & \multicolumn{1}{c|}{ VO } & \multicolumn{1}{c|}{ OVS } & \multicolumn{1}{c|}{ OV } & \multicolumn{1}{c|}{ SOV } & \multicolumn{1}{c|}{ OSV } & Kopā \\
\hline celt & 12 & 4 & 1 & 2 & 5 & 0 & 24 \\
\hline lasīt & 17 & 8 & 2 & 4 & 3 & 0 & 34 \\
\hline rakstit & 35 & 15 & 0 & 5 & 4 & 3 & 62 \\
\hline istenot & 10 & 10 & 2 & 1 & 1 & 2 & 26 \\
\hline & $\mathbf{7 4}$ & $\mathbf{3 7}$ & $\mathbf{5}$ & $\mathbf{1 2}$ & $\mathbf{1 3}$ & $\mathbf{5}$ & $\mathbf{1 4 6}$ \\
\hline & $\mathbf{5 1 \%}$ & $\mathbf{2 6 \%}$ & $\mathbf{3 \%}$ & $\mathbf{8 \%}$ & $\mathbf{9 \%}$ & $\mathbf{3 \%}$ & \\
\hline
\end{tabular}

1. tabula. Vārdu secības model̦i LVRK.

Ja papildinātājs atrodas aiz izteicēja, bieži - arī aplūkotās vienības beigās, tas parasti ir uzsvērts, un pamattonis mēdz būt līdzens vai nedaudz krītošs (sk. 2. attēlu), savukārt intensitātes līkne, izrunājot uzsvērto vārdu, sasniedz maksimālo punktu intonatīvajā vienībā, piem.:

(46) mēs cel̦am MĀJU;

(47) es kad rakstīju HRONIKU;

(48) lai vīrs varētu (ē) lasīt GRĀMATAS. (LVRK)

Ja papildinātājs atrodas aiz izteicēja, retāk uzsvērts ir izteicējs, piem.:

(49) ja vinga RAKSTĪS dzejoḷus tad rakstīs;

(50) tāda tradīcija ka dzejnieks tomēr LASA arī savu dzeju. (LVRK)

Uzsvērts var būt arī izteicējs un papildinātājs, piem.:

(51) un piegādātājs CEL PRASĪBU par nesamaksāto summu;

(52) kāpēc cilvēki labprāt LASA Ingas Jērumas GRĀMATAS. (LVRK)

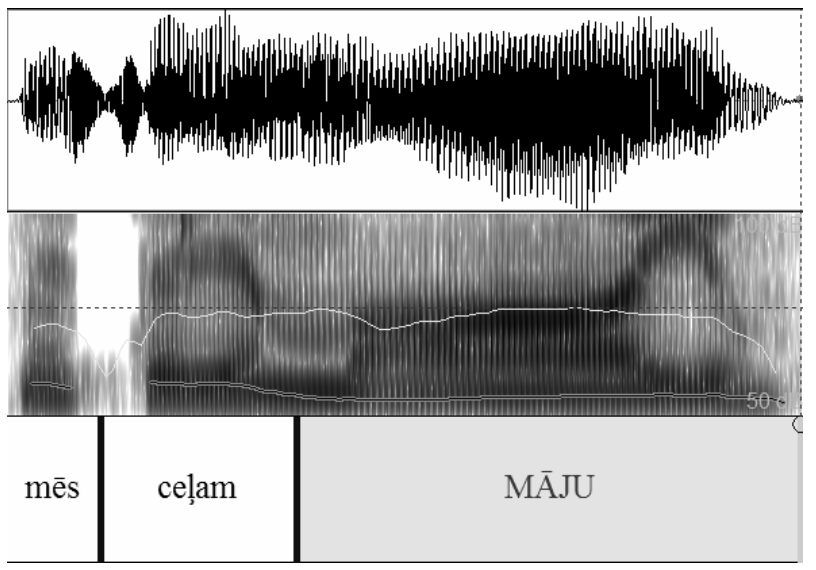

2. attēls. Izteikuma mēs ceļam māju (46) dinamiskā spektrogramma un oscilogramma. 
Ja papildinātājs atrodas izteicēja priekšā (secība OVS un SOV), papildinātājs netiek uzsvērts, bet tiek uzsvērts izteicējs (sk. 3. attēlu), piem.:

(53) Priekšcenzūra tam ko katrs LASA;

(54) Nu kā tu savādāk ķīniešu uzvārdu UZRAKSTĪSI. (LVRK)

Aplūkotajos piemēros, salīdzinot intonatīvās vienības uzsvērtos un neuzsvērtos vārdus, nav vērojamas izteiktas intensitātes svārstības, bet par uzsvērto vārdu signalizē pamattoņa virzības maiņa - tas ir kāpjoši krītošs, turklāt kritums ir samērā stāvs (sk. 3. attēlu).

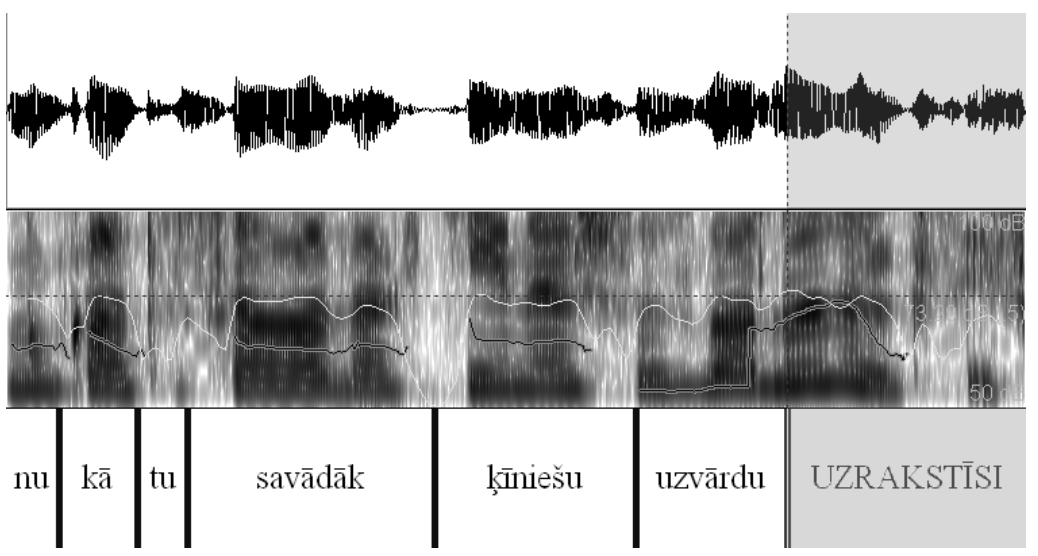

3. attēls. Izteikuma un kā tu savādāk ķīniešu uzvārdu uzrakstīsi (54) dinamiskā spektrogramma un oscilogramma.

Ja izteicējs neatrodas teikuma daḷas beigās, var būt uzsvērts izteicējs un teikuma priekšmets (sk. 4. attēlu):

(55) ko İSTENO Inženieru fakultātes PĀRSTĀVJI;

(56) ko İSTENOS Eiropas KOMISIJA. (LVRK)

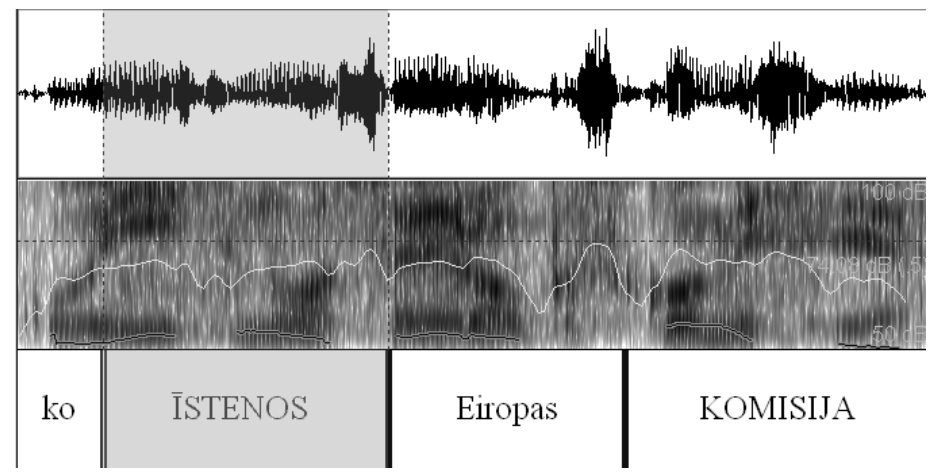

4. attēls. Izteikuma ko īstenos Eiropas Komisija (56) dinamiskā spektrogramma un oscilogramma. 
Eksperiments parāda, ka neatkarīgi no komponentu secības visbiežāk runā tiek uzsvērtas intonatīvās frāzes beigas. Ja ir uzsvērts kāds cits komponents, ne intonatīvās frāzes beigas, tas runā iegūst īpašu nozīmi - tiek izcelts vai pretstatīts kaut kam.

Kā redzams analizētajos piemēros, mainīta vārdu secība runātā tekstā nemaz nav tik bieži sastopama, acīmredzot vārdu secība ir svarīga tieši rakstītā tekstā un tā dal̦ēji norāda arī uz teikuma intonāciju. Salīdzinājumam 2. tabulā var aplūkot, kā atšksirīgai intonācijai varētu atbilst teikumi ar mainītu vārdu secību.

\begin{tabular}{|c|c|}
\hline $\begin{array}{l}\text { Runāts teksts (informācijas struktūru } \\
\text { atspoguḷo intonācija) }\end{array}$ & $\begin{array}{l}\text { Rakstīts teksts (informācijas struktūru } \\
\text { atspoguḷo vārdu secība) }\end{array}$ \\
\hline Mēs īstenosim PROJEKTU & Mès īstenosim PROJEKTU \\
\hline Mēs İSTENOSIM projektu & $\begin{array}{l}\text { Mès projektu ISTENOSIM } \\
\text { Istenosim mēs projektu }\end{array}$ \\
\hline MĒS īstenosim projektu & Projektu īstenosim MĒS \\
\hline
\end{tabular}

2. tabula. Vārdu secība rakstītā tekstā un intonācija runātā tekstā.

\section{Secinājumi}

Eksperiments parāda, kuri vārdu secības modelıi tiek biežāk lietoti, kas raksturīgs noteiktam vārdu secības modelim un kādā apkaimē tas tiek lietots. SVO ir latviešu valodas vārdu pamatsecība gan pēc lietojuma biežuma, gan arī pēc tā, ka tā drīzāk nekā citi vārdu secības modelii uzskatāma par pragmatiski nemarķētu vārdu secību, t. i., prototipisko vārdu secību.

Lielākajā daḷā ekscerpēto runas piemēru konstatēta secība SVO. Turklāt runātās valodas ekscerpti liecina, ka mainīta vārdu secība (resp., tāda, kas neatbilst modelim SVO) runā nemaz nav tik bieži sastopama (sk. 1. tabulu).

Aplūkotajā valodas materiālā - piemēros no LVRK - neatkarīgi no teikuma priekšmeta, izteicēja un papildinātāja secības visbiežāk uzsvērtas intonatīvās frāzes beigas. Ja intonatîvā frāze beidzas ar teikuma priekšmetu vai papildinātāju, paralēli uzsvaram intonatīvās frāzes beigās var būt uzsvērts arī izteicējs.

\section{Saīsinājumi un apzīmējumi}

O papildināâtāis

$\mathrm{S}$ teikuma priekšmets

$\mathrm{V}$ izteicējs

\section{Avoti}

Lìdzsvarotais mūsdienu latviešu valodas tekstu korpuss (miljons-2.0 un LVK2013). Pieejams: www.korpuss.lv.

Latviešu valodas runas korpuss. Nav publiski pieejams.

Latviešu valodas verbu valences datubāze. Nav publiski pieejama. 


\section{Literatūra}

1. Auzina, Ilze. 2013. Valodas suprasegmentālās jeb prosodiskās vienības. Latviešu valodas gramatika. Nītina, Daina, Grigorjevs, Juris (red.). Rīga: LU Latviešu valodas institūts, 104-122.

2. Ceplītis, Laimdots, Katlape, Nora. 1960. Izteiksmīgas runas pamati. Rīga: Zinātṇu akadēmija.

3. Ceplitis, Lajmdot. 1974. Analiz rechevoj intonacii. Riga: Zinatne.

4. Dryer, Matthew S. 2007. Word order. Clause Structure, Language Typology and Syntactic Description. Vol. 1, Shopen, Timothy (ed.). Second Edition. Cambridge University Press, 61-130.

5. Greenberg, Joseph H. 1990. Some universals of grammar with particular reference to the order of meaningful elements. On Language: Selected Writings of Joseph H. Greenberg. Denning, Keith and Kemmer, Suzanne (eds.). Stanford University Press, Stanford, California, 40-71.

6. Hajičová, Eva, Partee, Barbara H., Sgall, Petr. 1998. Topic-Focus Articulation, Tripartite Structures and Semantic Content. Dodrecht/Boston/London: Kluver Academic Publishers.

7. Hawkins, John A. 1983. Word Order Universals. New York: Academic Press.

8. Matthews, Peter H. 2007. Concise Dictionary of Linguistics. Oxford: University Press.

9. Nešpore Gunta, Saulīte Baiba. 2013. Latviešu valodas verbu valences mark̦ēšana. Valoda: nozìme un forma. 3. Teorija un metodologija valodniecībā. Kalnača, Andra, Lokmane, Ilze (red.). Rīga: LU Akadēmiskais apgāds, 97-106.

10. Nešpore, Gunta, Saulīte, Baiba, Grūzītis, Normunds, Garkāje, Ginta. 2012. Towards a Latvian Valency Lexicon. Human Language Technologies - The Baltic Perspective. Proceedings of the Fifth International Conference Baltic Human Language Technologies 2012. Vol. 247. Ed. by Arvi Tavast et al. Amsterdam, Berlin, Tokyo, Washington, DC: IOS Press, 154-161.

11. Pinnis, Mārcis, Auziña, Ilze, Goba, Kārlis. 2014. Designing the Latvian Speech Recognition Corpus. Proceedings of the $9^{\text {th }}$ edition of the Language Resources and Evaluation Conference (LREC'14). Ed. by Calzolari, Nicoletta et al. Reykjavik: European Language Resources Association (ELRA), 1574-1553.

12. Skujiņa, Valentīna (red.). 2007. Valodniecības pamatterminu skaidrojošā vārdnīca. Rīga: LU Latviešu valodas institūts.

13. Vallduví, Enric, Vilkuna, Marta. 1998. On Rheme and Kontrast. Culicover, Peter W., McNally, Louise (eds.). The Limits of Syntax (Syntax \& Semantics 29). San Diego: Academic Press, 79-108.

14. Zilgalve, Evelīna. 2009. Teikuma priekšmeta, izteicēja un papildinātāja secība publicistikas tekstos. Bakalaura darbs. Rīga: Latvijas Universitāte.

\section{Summary}

Latvian is a highly inflective language with a rather free word order. In general, the unmarked (i. e., the most common) order of elements in a sentence is SVO, however, OVS, SOV, OSV are possible and grammatically correct.

Data from the Latvian Valency Lexicon was used to analyse the word order models in Latvian. The paper first of all provides an analysis of SVO and other models. The differences from SVO sentences found in OVS, SOV and OSV were also analysed. The second part of the article contains the study of the Latvian Speech Recognition corpus sentences. The importance of prosodic features was explored in the selected examples with the changed word order. 